\title{
Usage of Online Resources by the Undergraduates Attached to the Faculty of Agriculture, Eastern University, Sri Lanka
}

\author{
J. Lavanya ${ }^{1}$, S. Santharooban ${ }^{2}$
}

\begin{abstract}
The online resources have emerged as one of the primary sources of information for teaching learning activity and research. Although the present era is mainly depending on online, all the students do not have adequate knowledge and skills necessary to exploit those resources. Hence it is essential for library professionals to analyses the online usage pattern of students before commencing awareness programmes. In this regard, the present study was designed to investigate the usage of online resources among the undergraduates of Faculty of Agriculture, Eastern University, Sri Lanka. Structured questionnaires were used to collect data among randomly selected 154 students. The study revealed that most of the students accesses Internet through smart phones for different educational purposes. Among them, purposes such as preparation for lecture and doing literature review are associated with academic year $(\mathrm{p}<0.05)$. Even though significant positive perception towards online resources $(\mathrm{p}<0.05)$ is observed, students are mostly unaware of both open access and university subscribed online resources, while they rely primarily on Google search. The factorial analysis revealed there are three latent constructs in the students' perceptions such as "Usefulness of online resources", "Awareness of online resources and the satisfaction of facilities" and "Challenges with online resources". The study also revealed the barriers to access online resources namely, slow Internet connectivity, unavailability of time, lack of awareness and viruses and other malware pop-ups. It is recommended that well-planned information literacy programme should be introduced for all students regardless of their academic year in order to access information in an effective way.
\end{abstract}

Keywords: Electronic resources, Exploratory Factor Analysis, Online resources, Online databases, Sri Lanka, Undergraduates

1 Assistant Librarian, Faculty of Health-Care Sciences, Eastern University, Sri Lanka. Email: 1.lavanya08@yahoo.com, (D) https://orcid.org/0000-0002-8567-8202

2 Senior Assistant Librarian, Faculty of Health-Care Sciences, Eastern University, Sri Lanka. Email: santharoobans@esn.ac.lk, (D) https://orcid.org/0000-0003-1984-875X

Received: 17 April 2018, Accepted revised version: 1 June 2018. 


\section{Introduction}

The emergence and advancement of information technology is the most significant factor affecting the scholarly communication. This technological advancement helps to obtain required information quickly and easily. In this technological era, the print medium is increasingly giving way to the electronic form of materials (Sharma, 2009). The transition from print to electronic medium apart from resulting in a growth of electronic information, has provided users with new tools and applications for information seeking and retrieval (Ani \& Ahiauzu, 2008; Islam \& Rahman, 2014). Hence, the libraries have to transform from its conventional approach of acquisition, organization and sharing of information, to modern and technological driven approaches. As such, many libraries have transformed into digital and virtual libraries, where books, journals and magazines have changed into e-books, ejournals, and e-magazines. One of the function of the technological driven and ICT based library services is to provide the users with readily available online information resources. The online information resources are those which can be accessible through World Wide Web such as e-journals, ebooks, e-databases, and online search engines; however, it comes under the broader term of electronic resources. E-resources are the electronic representation of information which can be accessed via electronic system and computer network (IFLA, 2012). Online information resources are invaluable research tools that complement the print-based resources and are becoming more and more important for the academic community, nowadays (Egberongbe, 2011). Moreover, the most remarkable and beneficial of online resources is that it supports the researcher irrespective of the time and geographical barrier.

Even though the online resources are readily available and quickest, they are still underutilized. There are number of factors contributing their underutilization. Lack of awareness and skills regarding the use of online resources is one of the important obstacles. Competencies related to usage of online resources are not only essential to retrieve the open access and subscription-based contents, but also imperative to accomplish their academic and research needs. Watts and Ibegbulam (2006) pointed out that the use of electronic information resources largely depends on the user's 
ability to navigate the maze of online resources available via technologybased terminals.

Therefore, making aware the users about the resources and their usage is one of the prime duties of librarians. Further, librarians are also accountable to identify the problems involving online information services and that will help them to deliver better services to their users by rectifying such problems. Therefore, this study was intended to identify the pattern and gaps in the use of online-resources among the students of Faculty of Agriculture, Eastern University, Sri Lanka. The specific objectives were to:

i. Find out the frequency, purpose and types of online resources used by the students for educational purpose

ii. Analyse the students' perception towards the online resources

iii. Identify the gaps in library services in providing online resources to users.

\section{Methodology}

The cross-sectional survey design was used in this study. The target population was the students from Faculty of Agriculture, Eastern University, Sri Lanka. The sample size was 158 which was calculated using Krejcie and Morgan (1970) formula and the sample was proportionately allocated to each academic year (Table 1$)$.

Table 1. Study population and sample

\begin{tabular}{lcc}
\hline Academic year & $\begin{array}{l}\text { Total } \\
\text { population }\end{array}$ & $\begin{array}{l}\text { Sample } \\
\text { size }\end{array}$ \\
\hline $1^{\text {st }}$ Year & 79 & 48 \\
$2^{\text {nd }}$ Year & 73 & 44 \\
$3^{\text {rd }}$ Year & 55 & 33 \\
$4^{\text {th }}$ Year & 54 & 33 \\
Total & 261 & 158 \\
\hline
\end{tabular}

Self-administrated questionnaire was designed to collect the data on demographic profile of respondents, online resource use, frequency and purpose, perception towards online resources, type of online resources used 
and barriers to use online resources. This instrument was tested and revised through pilot study conducted among selected students $(n=10)$ from the same faculty, before the survey. The data was collected by administering the questionnaire among the randomly selected students from each academic year.

The descriptive and inferential statistics were used to analyze the data. Under the inferential statistics, chi-square test was used to analyze the association of purpose of online resource use and academic year. Chi-square test of goodness-of-fit was used to check the difference between positive and negative perception towards online resources. In addition, exploratory factor analysis through principal component method was used to analyze the students' perception towards online resources. All the inferential statistics were performed at $95 \%$ confidence interval.

\section{Results and Discussion}

Demographic Profile

A total of 154 students responded from Faculty of Agriculture had participated in this study and therefore the response rate is $97 \%$. Among them, 36.4\% were male and 63.6\% were female. Further, academic year wise distribution showed that $29.2 \%$ of them were from first year, $28.6 \%$ of them were from second year, $21.4 \%$ from third year and $20.8 \%$ were from fourth year.

\section{Access to Online Resources}

Results of the analysis regarding accessibility of online resources revealed that most of the students access the internet through the smart phones (79\%), while $39 \%$ of them access the Internet within the library premises $(46.4 \%$ of males and $37.7 \%$ of females) (Table 2). Few percentage of students (male$12.5 \%$, Female-8.2\%) rely on Internet cafe and friends to access online resources.

It is really an alarm for the library sector to create a user-friendly environment within the library, so that users can access the Internet and other online resources. The result revealed that use of the physical library is much less than they had in the past. 
Table 2. Location of accessing the Internet

\begin{tabular}{ll}
\hline Place of accessing the Internet & Percentage (\%) \\
\hline Home/Hostel & 72.1 \\
Faculty & 56.5 \\
Library & 39.0 \\
Computer lab & 69.3 \\
Mobile devices (e.g. Smart phones) & 79.2 \\
Elsewhere (e.g. Internet cafe, friend) & 9.8 \\
\hline
\end{tabular}

Therefore, the libraries should create the environment with Internet access facilities. The physical resources coupled with Internet access facility will increase the library usage and avoid desertification of libraries in future.

\section{Account on Email and other Social Media}

Majority of them have the Email account (94.6\% of male, $93.9 \%$ of female) and Facebook account (94.6\% of male, $73.5 \%$ of female) and slight gender difference (but not statistically significant) was also noted in maintaining the accounts in Email and Facebook. The percentage of males having accounts on E mail and other social media exceeds the female. The social network sites such as Facebook and YouTube have been heavily used by the young generation, which led to keep those sites at the top of most-used online sources (OCLC, 2011). Hence, the librarians, should develop new strategies to market their resources through these mediums, which will bring the library to the palm of every youngster. The results also showed that only very few students have the account on social network for researchers, such as Research Gate (5.4\% of male, $1 \%$ of female) and Academia Edu (3.6\% of male and $3.1 \%$ of female). This may be due to lack of awareness about these sites among the students.

\section{Frequency of Using Online Resources}

This survey also revealed that majority of the students (77.3\%) spent two hours or less per day, on Internet. Meanwhile, 10.4\% of the respondents spent more than four hours on Internet. Even though $77.3 \%$ of the respondents access the Internet daily, only $59.1 \%$ of them access the online 
educational resources many times a day (Table 3). However, this is fairly good sign of using online educational resources by undergraduates.

\section{Table 3. Frequency of using online resources}

\begin{tabular}{ll}
\hline Frequency of the use of online resources & Percentage (\%) \\
\hline Many times, a day & 59.1 \\
Once a day & 18.2 \\
Several times a week & 21.4 \\
Several times a month & 0.6 \\
Less than once a month & 0.6 \\
\hline
\end{tabular}

Purposes of Using Online Resources

More than $90 \%$ of the respondents use online resources for preparing presentations and assignments. This kind of pattern had been reported by Daramola (2016), and Bassi and Camble (2011). Both agreed that students use e-resources mostly to prepare their assignments. Around $38 \%$ of the students use online resources for doing literature review for their research (Table 4).

Table 4. Purposes of using online resources

\begin{tabular}{ll}
\hline Purposes of using online resources & Percentage (\%) \\
\hline To prepare assignments & 94.2 \\
To prepare presentations & 91.6 \\
To find notes/facts for the lectures & 80.5 \\
To retrieve the diagrams and images & 77.9 \\
To watch and download videos & 77.9 \\
To update my knowledge & 74.7 \\
To prepare for the examination & 69.5 \\
To use e-mail communication & 65.6 \\
Social activities & 58.4 \\
To learn online (online education) & 42.9 \\
To do literature review for my research & 37.7 \\
\hline
\end{tabular}

The different purposes of online resources usage of respondents were compared with their academic year, using chi-square test of independence. 
The results revealed that there is significant association between academic year of the respondents and use of online resource to find notes/facts for the lectures $\left(\chi^{2}-10.14\right.$, df-3, $\left.\mathrm{p}<0.05\right)$ and also between academic year of the respondents and use of online resource to do literature review for research $\left(\chi^{2}-34.515, \mathrm{df}-3, \mathrm{p}<0.05\right)$. Whereas, association between academic year of the respondents and other purposes of using online resources are insignificant. Progressive increase was observed in the usage of online resources by the respondents from first to final academic year to prepare notes. Moreover, the usage of online resources for the purpose of literature review for research is comparatively high (78.1\%) among final year students (Table 5). Since the final year curriculum consists research project as a component, the final year students are using these resources considerably compared to other students.

Table 5. Purpose of using online resources across different academic years

Purpose of using Number of respondents in different

online resources academic years (\%)

\begin{tabular}{lllll} 
& $1^{\text {st }}$ year & $2^{\text {nd }}$ year & $3^{\text {rd }}$ year & $4^{\text {th }}$ year \\
\hline To find & $73.3 \%$ & $75 \%$ & $78.8 \%$ & $100 \%$
\end{tabular}

notes/facts for

the lectures

$\begin{array}{llll}\text { To do literature } \quad 35.6 \% & 31.8 \% & 9.1 \% & 78.1 \%\end{array}$

review for

research

\section{Methods of Learning Online Resource Usage Skills}

The respondents were asked to select the way that they learn to use the online resources. In response, $74 \%$ of them reported that they learnt through self-study. This finding confirm the results of the study conducted by Stella (2013), which revealed that $78.8 \%$ acquire their internet skills either online or through teaching by colleagues or friend. The author also reported that continuing education and self-study were the most preferred ways to acquire new skills. Another study reported that the majority of the users preferred self-learning and they believed that it was the most effective mode of learning (Rehman \& Ramzy, 2004). According to the adult learning theories, 
the adults normally prefer to acquire the knowledge through self-learning, which is a good approach for lifelong learning. Therefore, the librarians should function as a facilitator for self-learning through conducting workshops and training programmes in these aspects. However, the results revealed that the library's contribution on this kind of training programmes is very limited (Table 6).

Table 6. Methods of learning online resource usage skills

\begin{tabular}{lr}
\hline Methods of learning online resource usage skills & $\%$ \\
\hline Self-study (reading books/articles, tutorials, etc.) & 74.0 \\
Family, friend, or colleague & 30.5 \\
Formal course & 14.3 \\
Library workshop & 2.6 \\
Attending special training courses and workshops & 3.9 \\
\hline
\end{tabular}

\section{Types of Online Resources Being Used}

Highest usage of online resource was observed for online search engines (94\%), followed by Wikipedia (71.4\%). However, the usage of online databases (14.3\%), e-books (22.7\%), e-journals (14.9\%), and digitized theses and dissertations (12.3\%) are considerably low. This is in line with the findings of Okello-Obura and Ikoja-Odongo (2010). The particular study revealed that $63 \%$ of the respondents used Internet search engines, while only $13.5 \%, 11.6 \%$ and $7.5 \%$ and $5.6 \%$ used e-books, CD-ROM, e-journals and scholarly databases respectively. The students in the absence of proper awareness of online resources, prefer to do a general Internet searching rather than effective database searching to find scholarly articles for their academic and research needs. Nemati Anaraki and Babalhavaeji (2013) also pointed out that where students are not aware of existence of e-databases they tend to use general search engines to meet their information needs. Wjetunge (2014) pointed out that users are motivated to utilize search engines and Wikipedia over scholarly digital resources. Dilek-Kayaoglu (2008) affirmed that one of the barriers in relation to the use of e-resources as reported by $42.7 \%$ of the respondents of the study is lack of awareness regarding the e-resources services in their library. Das and Maharana (2013) stated that awareness is core to usage of electronic information. As such, librarians should play a major role in assisting the students to enhance the usage of online databases to maximum extent (Nikam \& Pramodini, 2007) 
and also in training the students in effective Internet searching through different databases.

Further, this study also revealed that the students who are using search engines often use the Google (95.9\%), nevertheless, there is an Open Access Journals Search Engine (OAJSE), which gives full text and open access articles. It has been noted that OAJSE search engine is used only by $4.1 \%$ of the students.

During this study period, the University Grants Commission provided access to Wiley Online and Sage Research Methods via UGC consortium and the Eastern University, Sri Lanka subscribed HINARI, AGORA, OARE from Research4life. However, assessment results indicated that usage of these databases is considerably low. Even though, library conducts regular awareness programme for academic staff members, it is not sufficient to increase the level of awareness among the students. Hence, it is recommended to conduct regular awareness programmes for students, too.

At this juncture, it is also important to consider the reliability of information and style of citing references. There is no doubt that databases provide evaluated sources of information and resources are relevant, reliable and authoritative. As information managers, librarians have fullest responsibility on identifying problems of students regarding effective online searching.

\section{Perception of Students towards Online Resources}

The perception of students regarding the online resources was tested using twelve statements, including three negative statements (statement no. 2, 4 and 11 in Table 7). A chi-square test of goodness-of-fit was performed to determine the distribution of positive and negative perceptions of respondents. Significant difference was observed between the positive and negative perception for all the statements $(\mathrm{p}<0.05)$, except three statements, namely "online information resources are expensive (statement no.5)", "I am aware of Open Access databases available in our university (statement no.8)" and "I am satisfied with the facilities to access online resources in our university (statement no.9)". This study highlighted that students expressed positive perception towards online resources. Moreover, the statement no. 8 
showed that there is lack of awareness among the students about the online resources, which implies that library workshops are not adequately conducted for students. The statement no. 9 indicates that the students are not well satisfied with the facilities available in the university to access the online resources.

Table 7. Students perception towards online resources

\begin{tabular}{|c|c|c|}
\hline Statements & $\begin{array}{l}\text { Positive } \\
\text { perception } \\
(\%)\end{array}$ & $\begin{array}{l}\text { Negative } \\
\text { perception } \\
(\%)\end{array}$ \\
\hline $\begin{array}{l}\text { 1. Online resources are more useful than printed } \\
\text { resources }\end{array}$ & $72.7 * *$ & 27.3 \\
\hline 2. Internet resources are not reliable & 29.9 & $70.1^{* *}$ \\
\hline 3. Online resources are easy to use & $89.6 * *$ & 10.4 \\
\hline 4. Searching on the Internet is difficult & 15.6 & $84.4^{* *}$ \\
\hline 5. Online information resources are expensive & 42.9 & 57.1 \\
\hline 6. Online resources provide up-to-date information & $75.3 * *$ & 24.7 \\
\hline $\begin{array}{l}\text { 7. Lecturers/Supervisor advise/s me to use online } \\
\text { resources }\end{array}$ & $70.1^{* *}$ & 29.9 \\
\hline $\begin{array}{l}\text { 8. I am aware of Open Access databases available in } \\
\text { our university }\end{array}$ & 52.6 & 47.4 \\
\hline $\begin{array}{l}\text { 9. I am satisfied with the facilities to access online } \\
\text { resources in our university }\end{array}$ & 49.4 & 50.6 \\
\hline $\begin{array}{l}\text { 10. I highly depend on online resources to prepare my } \\
\text { assignments or research report }\end{array}$ & $83.1^{* *}$ & 16.9 \\
\hline $\begin{array}{l}\text { 11. I do not need online information resources for my } \\
\text { education }\end{array}$ & 7.8 & $92.2^{* *}$ \\
\hline 12. Online resources help my learning activities & $89 * *$ & 11 \\
\hline
\end{tabular}

The Exploratory Factor Analysis (EFA) was also conducted on these twelve items of perception to determine the underlying construct of perceptions. In general, EFA is used to deduce the latent variables which unobservable from the observable variables and known as reducing dimensionality (Bartholomew, Knott, \& Moustaki, 2011). There are several methods of factor extractions. This particular study used Principal component extraction method with Varimax rotation. 
This analysis revealed three factor (Table 8 ) solutions explaining $57.5 \%$ of the total variance. Items were considered to have loaded if they had a factor loading of 0.4 or more. Two statements were not included in any of the factors.

Table 8. Factor analysis of students' perception regarding online resources

\begin{tabular}{|c|c|c|}
\hline Factors & Statements & $\begin{array}{l}\text { Factor } \\
\text { loading }\end{array}$ \\
\hline \multirow{4}{*}{$\begin{array}{l}\text { Factor } 1 \\
\text { Usefulness } \\
\text { of online } \\
\text { resources. }\end{array}$} & Online resources help my learning activities & 0.843 \\
\hline & $\begin{array}{l}\text { I highly depend on online resources to prepare my } \\
\text { assignments or research report }\end{array}$ & 0.772 \\
\hline & $\begin{array}{l}\text { I do not need online information resources for my } \\
\text { education }\end{array}$ & -0.752 \\
\hline & Online resources are easy to use & 0.682 \\
\hline \multirow{3}{*}{$\begin{array}{l}\text { Factor } 2 \\
\text { Awareness } \\
\text { of online } \\
\text { resources \& } \\
\text { satisfaction } \\
\text { of facilities. }\end{array}$} & $\begin{array}{l}\text { I am aware of Open Access databases available in } \\
\text { our university }\end{array}$ & 0.836 \\
\hline & $\begin{array}{l}\text { Lecturers/Supervisor advise/s me to use online } \\
\text { resources }\end{array}$ & 0.687 \\
\hline & $\begin{array}{l}\text { I am satisfied with the facilities to access online } \\
\text { resources in our university }\end{array}$ & 0.667 \\
\hline Factor 3 & Online information resources are expensive & 0.784 \\
\hline \multirow{2}{*}{$\begin{array}{l}\text { Challenges } \\
\text { with online } \\
\text { resources }\end{array}$} & Internet resources are not reliable & 0.679 \\
\hline & Searching on the Internet is difficult & 0.597 \\
\hline
\end{tabular}

As an overall picture, there are three latent variables of students' perceptions towards online resources and the facilities to access those resources. Those latent constructs are "usefulness of online resources", "awareness of online resources and the satisfaction of facilities" and "challenges with online resources".

Four statements which measure the latent construct - "usefulness of online resources" converge together in the factor 1 and this factor explain with $26 \%$ of total variance. Among these statements, online resources are easy to use, helps to prepare assignments and research reports, and helps in learning 
activities are correlated positively with each other. However, the statement "I do not need online information resources for my education" is negatively correlated with others. It is obvious that those who use the online resources for their studies, always need that. Hence, it results in negative correlation. Library users' attitude towards use of electronic information resources may change if they are able to access their need. Kwadzo (2015) found out in a study that $71.9 \%$ of the respondents found e-resources useful because they could search all database simultaneously. This was followed by $65.6 \%$ who said they use resources because they are available all the time (24/7).

The second latent construct-"awareness of online resources and the satisfaction of facilities" has three statements and this factor explain 17.8\% of total variance of data. Awareness of Open Access databases among the students and the advice of lecturers or supervisors converge together showing that students were motivated by lecturers to use online resources and it helps them to be aware of online resources.

The third latent construct-“"challenges with online resources" has three variables and this factor explain $13 \%$ of total variance of data. This includes major challenges that students face such as unaffordable expensiveness, poor reliability of online resources and lack of skill for effective searching. These are all negative perceptions. Being in a developing country, expensiveness of online material is a major issue. Although this issue has been rectified to certain extent through the formation of UGC consortia, still the issue is prevailing among the university undergraduates due to the lack of awareness. The second major issue is the reliability of online resources. A study among undergraduates by Kim and Sin (2007) found that accuracy/trustworthiness had highest score among the criteria to select the online resources. Due to the readily accessible technology, unauthenticated and unreliable information are increasing on the Internet and it poses the serious challenge to the academia. The third issue is the lack of effective searching skill among the undergraduates. This can be rectified if the librarians with support of faculty engage regular training programme to the undergraduates. 
Barriers Related to Accessing Online Resources

Analyzing the barriers that students face is an important task for the librarians to make recommendation to the administration and to develop strategies to overcome such barriers. As such this study identified that the slow Internet connectivity (62.3\%) is the major barrier to access the online resources (Table 9). This may be a common barrier in developing countries. Few studies from other developing countries also pointed out that unreliable or slow Internet connectivity is challenge for accessing e-resources (Daramola, 2016; Omeluzor, Akibu, \& Akinwoye, 2016).

As Internet has become an unavoidable necessity for every higher educational institutions (Bhat \& Mudhol, 2014), it is essential to maintain Internet connectivity with good band width, through the LAN and Wi-Fi facilities. Other major barriers were unavailability of time (48.7\%), lack of awareness (46.1\%) and viruses and other malware pop-ups (42.9\%).

\section{Table 9. Barriers to access online resources}

\begin{tabular}{ll}
\hline Barriers & $\%$ \\
\hline Slow Internet connectivity & 62.3 \\
Unavailability of time & 48.7 \\
Lack of awareness of online information resources & 46.1 \\
Virus and other malware pop-ups & 42.9 \\
Information overload & 37.7 \\
Inaccessibility to important online resources & 27.9 \\
Unreliable information on the Internet & 27.3 \\
Lack of searching/browsing skills & 24.7 \\
Not being good at English language to use the resources & 16.2 \\
\hline
\end{tabular}

\section{Conclusion}

Nowadays the online resources have emerged as most powerful medium for information retrieval. The online resources are essential tools for empowering students, academician and researchers. This study revealed that the students attached to the Faculty of Agriculture Science, Eastern University, Sri Lanka are using internet regularly for educational and entertainment purposes. However, majority of the respondents are unaware of the Online databases provided by the UGC and university subscribed 
online resources. Moreover, the open access resources such as, e- books and e-journals are very helpful for academic learning and scholarly research. Instead, they highly depend on Google search, and few of them use and aware of online databases. The study also revealed that awareness programme conducted for students by the library is limited and mostly students learned about online resources through self-study. Further, the study identified different purposes for which online resources are used and found that these purposes are more common among the respondents from different academic year. Use of online resources for preparing notes and literature review is highly associated with final year students compared to other academic years. In addition, students have positive perception towards online resources while awareness of Open Access resources and the satisfaction with facilities available in the university to access online resources have negative perception. Factor analysis revealed three underlying latent constructs from the perceptions of students. Those constructs are "usefulness of online resources", "awareness of online resources and the satisfaction of facilities" and "challenges with online resources". The major barrier to use online resources indicated by the students is slow Internet connectivity. In addition, lack of awareness regarding online information resources, unavailability of time and Virus and other malware pop-ups were highlighted as barriers. Hence, it is recommended that the university has to take initiatives to organize user awareness sessions and training programme for the students on regular basis to improve the information literacy skills and information retrieval skills, which would promote the usage of online resources.

\section{References}

Ani, O. E., \& Ahiauzu, B. (2008). Towards effective development of electronic information resources in Nigerian university libraries. Library Management, 29(6/7), 504-514.

Bartholomew, D. J., Knott, M., \& Moustaki, I. (2011). Latent variable models and factor analysis: A unified approach (3rd ed.). West Sussex, UK: John Wiley \& Sons.

Bassi, M. D., \& Camble, E. (2011). Gender differences in use of electronic resources in university libraries of Adamawa State, Nigeria. Library Philosophy \& Practice, 7-15. 
Bhat, I., \& V. Mudhol, M. (2014). Use of e-resources by faculty members and students of Sher-E-Kashmir Institute of Medical Science (SKIMS). DESIDOC Journal of Library \& Information Technology, 34, 28-34.

Daramola, C. F. (2016). Perception and utilization of electronic resources by undergraduate students: The case of the Federal University of Technology Library, Akure. American Journal of Educational Research, 4(5), 366-370. https://doi.org/10.12691/education-4-5-1

Das, P., \& Maharana, R. K. (2013). Access, awareness \& use of electronic information resources by research scholars of Berhampur University: A study. American International Journal of Research in Humanities, Arts and Social Sciences, 3(2), 254-259.

Dilek-Kayaoglu, H. (2008). Use of electronic journals by Faculty at Istanbul University, Turkey: The results of a survey. Journal of Academic Librarianship, 34(3), 239-247. https://doi.org/10.1016/j.acalib.2008.03.007

Egberongbe, H. S. (2011). The use and impact of electronic resources at the University of Lagos. Library Philosophy and Practice. Retrieved from https://digitalcommons.unl.edu/cgi/viewcontent.cgi?article=1490\&cont ext=libphilprac

IFLA. (2012). Key issues for e-resource collection development: A guide for libraries. Hague: International Federation of Library Associations and Institutions. https://doi.org/http://www.ifla.org/publications/keyissues-for-e-resource-collection-development-a-guide-for-libraries

Islam, M. M., \& Rahman, M. A. (2014). Assessing information literacy competency of Arts Faculty students at the University of Dhaka. Library Philosophy and Practice 2018. Retrieved from https://digitalcommons.unl.edu/libphilprac/1110/

Kim, K. S., \& Sin, S. C. J. (2007). Perception and selection of information sources by undergraduate students: Effects of avoidant style, onfidence, and personal control in problem-solving. Journal of Academic Librarianship, 33(6), 655-665. https://doi.org/10.1016/j.acalib.2007.09.012

Krejcie, R. V, \& Morgan, D. W. (1970). Determining sample size for 
research activities. Education and Psychological Measurement, 30, 607-610. https://doi.org/10.1177/001316447003000308

Kwadzo, G. (2015). Awareness and usage of electronic databases by Geography and Resource Development Information Studies graduate students in the University of Ghana. Library Philosophy and Practice, 1210. Retrieved from http://digitalcommons.unl.edu/libphilprac/1210

Nemati Anaraki, L., \& Babalhavaeji, F. (2013). Investigating the awareness and ability of medical students in using electronic resources of the integrated digital library portal of Iran. The Electronic Library, 31(1), 70-83. https://doi.org/10.1108/02640471311299146

Nikam, K., \& Pramodini, B. (2007). Use of e-journals and databases by the academic community. Annals of Library and Information Studies, 54, $19-22$.

OCLC (2011). Perceptions of libraries, 2010: context and community. Ohio: OCLC, Online Computer Library Centre. Retrieved from http://www.oclc.org/reports/2010perceptions/2010perceptions_all.pdf\% 5Cnhttp://scholar.google.com/scholar?hl=en\&btnG=Search\&q=intitle:P erceptions+of+Libraries,+2010\#2

Okello-Obura, C., \& Ikoja-Odongo, J. . (2010). Electronic information seeking among LIS postgraduate students at Makerere University, Uganda. Library Philosophy and Practice, 499. Retrived from https://digitalcommons.unl.edu/cgi/viewcontent.cgi?article=1517\&cont ext=libphilprac

Omeluzor, U., Akibu, A., \& Akinwoye, A. (2016). Students' Perception, Use and Challenges of Electronic Information Resources in Federal University of Petroleum Resources Effurun Library in Nigeria. Library Philosophy and Practice, 1428. Retrieved from http://digitalcommons.unl.edu/libphilprac/1428

Rehman, S., \& Ramzy, V. (2004). Awareness and use of electronic information resources at the Health Sciences Center of Kuwait University. Library Review, 53(3), 150-156.

Sharma, C. (2009). Use and impact of e-resources at Guru Gobind Singh Indraprastha University (India): A case study. Electronic Journal of Academic and Special Librarianship, 10(1). Retrived from 
http://southernlibrarianship.icaap.org/content/v10n01/sharma_c01.html

Stella, E. I. (2013). Users and Internet skills: A report from Delta State University, Abraka, Nigeria. Electronic Journal of Academic and Special Librarianship, 6(3). Retrived from http://southernlibrarianship.icaap.org/content/v06n03/igun_s01.htm

Watts, C., \& Ibegbulam, I. (2006). Access to electronic healthcare information resources in developing countries: experiences from the Medical Library, College of Medicine, University of Nigeria. IFLA Journal, 32(1). Retrived from http://journals.sagepub.com/doi/abs/10.1177/0340035206063903

Wijetunge, P. (2014). Digital information resource preferences of undergraduates: with special reference to three health science faculties of University of Peradeniya. Paper presented at Peradeniya University International Research Sessions. University of Peradeniya, Peradeniya. 